\title{
Mechanosensitivity of $\mathrm{Na}_{\mathrm{v}} 1.5$ sodium channels is regulated by specific $\beta$-subunits
}

\author{
Enrico Leipold ${ }^{1}$ (D)
}

Received: 28 October 2019 /Revised: 14 November 2019 / Accepted: 14 November 2019 /Published online: 20 November 2019

(C) Springer-Verlag GmbH Germany, part of Springer Nature 2019

Mechanically active organs such as the heart, skeletal muscles, and the gastrointestinal tract contain complex neuronal networks that generate and coordinate contraction and relaxation of these organs. In addition to the generation of movement, contractile organs can also recognize and respond to mechanical stimuli via mechanoelectrical feedback. The molecular targets that sense mechanical force and translate it into electrical signals are ion channels located in the excitable membranes of neurons and muscle cells. Among them are included specialized mechano-gated channels as well as ion channels with distinct primary gating stimuli, whose functions are also modulated by mechanical stress as it occurs during cellular stretch and compression. Voltage-gated sodium $\left(\mathrm{Na}_{\mathrm{V}}\right)$ channels belong to the latter group. These channels are essential elements for the electrical communication of excitable cells. They initiate and shape action potentials by permitting influx of $\mathrm{Na}^{+}$ions into cells in response to small membrane depolarizations. $\mathrm{Na}_{\mathrm{V}}$ channels are macromolecular protein complexes composed of a large pore-forming $\alpha$-subunit and one or more smaller $\beta$-subunits with regulatory functions [4]. The family of human $\mathrm{Na}_{\mathrm{V}}$ channels consists of nine $\alpha$-subunits $\left(\mathrm{Na}_{\mathrm{V}} 1.1-1.9\right)$ and four $\mathrm{Na}_{\mathrm{V}} \beta$-subunits $(\beta 1-4)$, which all possess tissue-specific expression patterns $[3,5]$. Mechanomodulation of $\alpha$-subunit $\mathrm{Na}_{\mathrm{V}} 1.5$ is of particular interest because this channel contributes to action potential generation in cardiac myocytes and smooth muscle cells of the gut where it is inherently exposed to mechanical load [2, 7]. Although the mechanosensitivity of $\mathrm{Na}_{\mathrm{V}} 1.5 \alpha$-subunits is well established $[1,6]$, it has not been demonstrated yet if

This article is a commentary to the original article https://doi.org/10.1007/ s00424-019-02321-z

Enrico Leipold

Enrico.Leipold@uni-luebeck.de

1 Department of Anesthesiology and Intensive Care, University of Luebeck, Luebeck, Germany and how associated $\beta$-subunits can modulate the channel's response to mechanical stimuli.

In this issue, Maroni et al. show that $\beta 1$ - and $\beta 3$-subunits differentially modulate the response of $\mathrm{Na}_{\mathrm{V}} 1.5$ to mechanical stimulation. In their paper entitled " $\beta 1$ and $\beta 3$ subunits amplify mechanosensitivity of the cardiac voltage-gated sodium channel $\mathrm{Na}_{\mathrm{V}} 1.5$," the authors describe whole-cell patch-clamp recordings on human embryonic kidney (HEK) cells expressing $\mathrm{Na}_{\mathrm{V}} 1.5 \alpha$-subunits either alone or in combination with $\beta 1$ or $\beta 3$, and expose the cells to shear stress generated by a standardized perfusion system. Using this approach, they confirmed that mechanical stress accelerates activation and inactivation of $\mathrm{Na}_{\mathrm{V}} 1.5$ and demonstrate that only the presence of $\beta 3$ but not $\beta 1$ enhances the mechano-induced acceleration of channel activation and inactivation. Previous work has revealed that mechanical stress stabilizes inactivated states of $\mathrm{Na}_{\mathrm{V}} 1.5$ by shifting the channel voltage-dependence of steady-state inactivation to more hyperpolarized potentials [1]. Maroni et al. analyze this effect in absence and presence of $\beta 1$ - or $\beta 3$-subunits and show that particularly, $\beta 3$ increases the shear stress-triggered hyperpolarizing shift of channel inactivation, thus effectively increasing the voltage window in which mechanomodulation of $\mathrm{Na}_{\mathrm{V}} 1.5$ cannels occurs.

The reported findings strengthen the hypothesis that modulation of $\mathrm{Na}_{\mathrm{V}} 1.5$ channel activity is part of the mechanoelectrical feedback in heart and gut tissue, and suggest that $\mathrm{Na}_{\mathrm{V}} 1.5$-dependent mechanoelectrical feedback depends strongly on the type of $\beta$-subunit present in $\mathrm{Na}_{\mathrm{V}} 1.5$ channel complexes.

\section{References}

1. Beyder A, Rae JL, Bernard C, Strege PR, Sachs F, Farrugia G (2010) Mechanosensitivity of $\mathrm{Na}_{\mathrm{V}} 1.5$, a voltage-sensitive sodium channel. J Physiol 588(Pt 24):4969-4985

2. Beyder A, Mazzone A, Strege PR, Tester DJ, Saito YA, Bernard CE, Enders FT, Ek WE, Schmidt PT, Dlugosz A, Lindberg G, Karling P, Ohlsson B, Gazouli M, Nardone G, Cuomo R, Usai-Satta P, Galeazzi 
F, Neri M, Portincasa P, Bellini M, Barbara G, Camilleri M, Locke GR, Talley NJ, D'Amato M, Ackerman MJ, Farrugia G (2014) Lossof-function of the voltage-gated sodium channel $\mathrm{Na}_{\mathrm{V}} 1.5$ (channelopathies) in patients with irritable bowel syndrome. Gastroenterology 146(7):1659-1668

3. Brackenbury WJ, Isom LL (2011) $\mathrm{Na}^{+}$channel $\beta$ subunits: overachievers of the ion channel family. Front Pharmacol 2:53

4. Catterall WA (2012) Voltage-gated sodium channels at 60: structure, function and pathophysiology. J Physiol 590(11):2577-2589

5. Catterall WA, Goldin AL, Waxman SG (2005) International Union of Pharmacology. XLVII. Nomenclature and structure-function relationships of voltage-gated sodium channels. Pharmacol Rev 57(4):397-409

6. Morris CE, Juranka PF (2007) $\mathrm{Na}_{\mathrm{V}}$ channel mechanosensitivity: activation and inactivation accelerate reversibly with stretch. Biophys J 93(3):822-833

7. Rook MB, Evers MM, Vos MA, Bierhuizen MF (2012) Biology of cardiac sodium channel $\mathrm{Na}_{\mathrm{V}} 1.5$ expression. Cardiovasc Res 93(1): $12-23$

Publisher's note Springer Nature remains neutral with regard to jurisdictional claims in published maps and institutional affiliations. 